\title{
ANALISIS KESALAHAN SISWA DALAM MENYELESAIKAN SOAL OPERASI PECAHAN BENTUK ALJABAR SMP
}

\author{
Jesisca L. T. Mangi ${ }^{1}$, Elsy Senides H. Taunu ${ }^{2}$, Mega R. Wulandari ${ }^{3}$, Anggriati Ledu \\ Ngaba $^{4 *}$, Yuliana Tamu Ina Nuhamara ${ }^{5}$, Mayun Erawati Nggaba ${ }^{6}$ \\ 1,2,3,4,5,6 Universitas Kristen Wira Wacana Sumba \\ *Corresponding Author: $\otimes$ anggraitiledungaba@unkriswina.ac.id
}

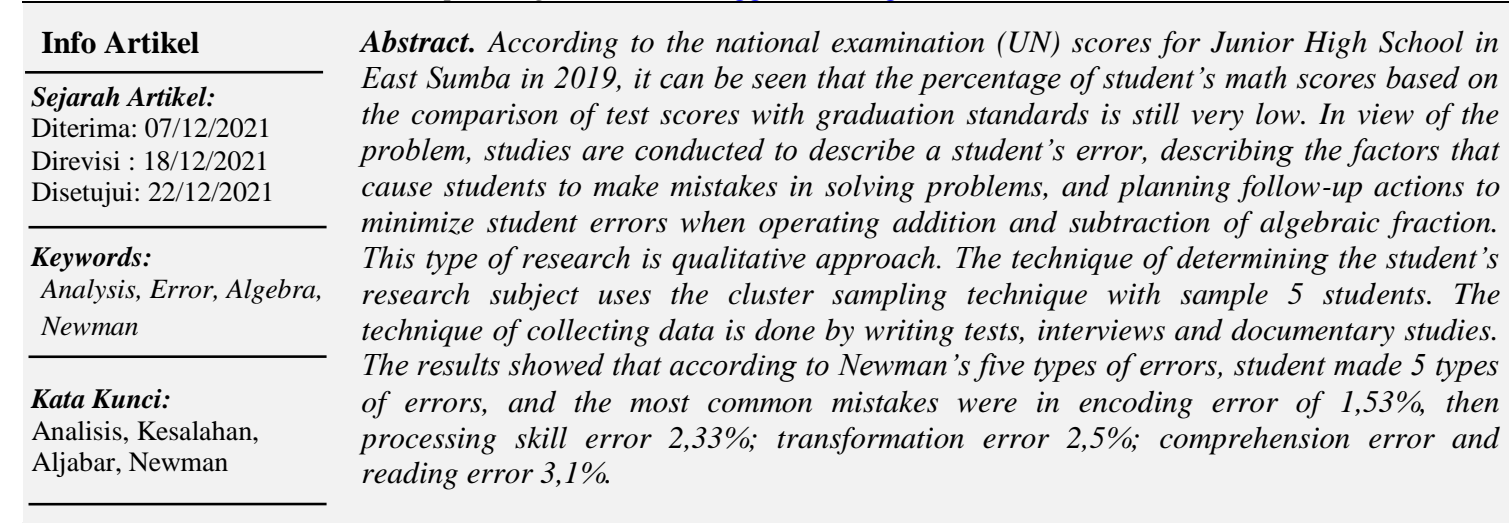

\begin{abstract}
Abstrak. Berdasarkan data nilai Ujian Nasional (UN) SMP di Sumba Timur pada tahun 2019, dapat diketahui persentase nilai matematika siswa berdasarkan perbandingan nilai hasil ujian dengan standar kelulusan, masih tergolong sangat rendah. Dilihat dari masalah tersebut, maka dilakukan penelitian yang bertujuan untuk mendeskripsikan kesalahan siswa, faktor penyebab kesalahan siswa, serta merencanakan tindak lanjut untuk meminimalisir kesalahan siswa ketika mengoperasikan penjumlahan dan pengurangan pecahan bentuk aljabar. Jenis penelitian ini adalah kualitatif dengan pendekatan kualitatif deskriptif. Penentuan subjek penelitian menggunakan teknik sampel klaster dengan jumlah 5 orang siswa. Teknik mengumpulkan data dilakukan dengan tes tertulis, wawancara dan dokumentasi. Hasil penelitian menunjukkan bahwa kelima tipe kesalahan menurut Newman, siswa melakukan 5 jenis kesalahan, dan kesalahan yang paling banyak dilakukan yaitu pada kesalahan penentuan jawaban akhir sebesar $1,53 \%$, selanjutnya kesalahan proses 2,33\%; kesalahan transformasi 2,5\%; kesalahan memahami dan kesalahan membaca $3,1 \%$
\end{abstract}

How to Cite: Mangi, J. L. T., Taunu, E. S. H., Wulandari, M. R., Ngaba, A. L., Nuhamara, Y. T. I., \& Nggaba, M. E. (2022). ANALISIS KESALAHAN SISWA DALAM MENYELESAIKAN SOAL OPERASI PECAHAN BENTUK ALJABAR SMP. Prima Magistra: Jurnal Ilmiah Kependidikan, 3(1), 85-91. https://doi.org/10.37478/jpm.v3i1.1404

\section{Alamat korespondensi:}

Jl. R. Soeprapto No 35, Waingapu, Kabupaten Sumba Timur, Provinsi Nusa Tenggara Timur.

\section{Penerbit:}

Program Studi PGSD Universitas Flores. @ primagistrauniflor@gmail.com

@ anggriatiledungaba@unkriswina.ac.id 


\section{PENDAHULUAN}

Salah satu ilmu pengetahuan yang membantu pengembangan teknologi dan ilmu pengetahuan adalah matematika (Siagian, 2016). Terdapat empat bagian dari matematika, yaitu aljabar, aritmatika, geometris dan analisis, dimana analisis aritmatika meliputi statistika dan teori bilangan (Wandini, 2019). Matematika ialah mata pelajaran pokok yang dipelajari di setiap tingkatan pendidikan. Oleh sebab itu, dalam Permendiknas Nomor 22 tahun 2006 tentang Standar Isi untuk Satuan Pendidikan Dasar dan Menengah (Depdiknas, 2006) menyebutkan beberapa tujuan mempelajari matematika, antara lain melatih siswa agar dapat mempunyai pemahaman tentang konsep matematika yang baik, dapat mencari solusi masalah matematika, serta menghargai manfaat dari pelajaran matematika. Seorang siswa dikatakan berhasil dalam belajar matematika jika telah mencapai tujuan tersebut. Pada kenyataannya hal-hal tersebut tidak ditemukan dalam kegiatan pembelajaran, dibuktikan dengan rendahnya penguasaan matematika siswa.

Berdasarkan data nilai Ujian Nasional (UN) SMP di Sumba Timur tahun 2019, dapat diketahui bahwa capaian rata-rata nilai pelajaran Bahasa Indonesia adalah 56,99; nilai pelajaran Bahasa Inggris adalah 37,26; nilai pelajaran matematika adalah 34,79 ; nilai pelajaran IPA adalah 36,41 (Kemendikbud, 2019). Sedangkan standar kelulusan setiap mata pelajaran paling rendah adalah 40,00. Sehingga dapat disimpulkan bahwa, persentase nilai matematika siswa berdasarkan perbandingan nilai hasil ujian dengan standar kelulusan, masih tergolong sangat rendah.

Beberapa faktor penyebab rendahnya nilai siswa antara lain sedikitnya minat siswa terhadap pelajaran matematika, siswa kurang berkonsentrasi dalam memperhatikan guru yang sedang menjelaskan, kurangnya pemahaman konsep matematika dasar siswa, serta ketidakdisiplinan siswa dalam mengumpulkan tugas yang diberikan oleh guru (Oktaviani et al., 2020). Selain rendahnya prestasi siswa, masalah yang sering terjadi terkait pelajaran matematika yaitu, siswa banyak melakukan kesalahan ketika menyelesaikan soal-soal matematika. Kesalahan merupakan penyimpangan terhadap aturan yang berlaku (Ananda et al., 2018). Kesalahan-kesalahan umum yang sering terjadi yaitu kesalahan dalam memahami konsep, kesalahan penggunaan rumus matematika, kesalahan perhitungan maupun kesalahan dalam penggunaan langkah-langkah penyelesaian (Rohmah \& Sutiarso, 2017). Kendala tersebut juga ditemukan di SMP Negeri 1 Waingapu, khususnya dalam mengoperasikan penjumlahan dan pengurangan pecahan bentuk aljabar. Semua kesalahan umumnya ditemukan saat siswa mengerjakan ujian, ulangan ataupun dari tugas-tugas yang diberikan guru.

Siswa dikatakan melakukan kesalahan memahami konsep operasi hitung aljabar apabila siswa salah memahami konsep tersebut. Sebagai salah satu contoh kesalahan membaca soal yaitu pada soal “ $\frac{10 y}{7}$ ” tetapi

siswa hanya menulis “ $\frac{10}{7}$ ” tidak menuliskan

variabel $\mathrm{y}$, hal ini dapat dikatakan sebagai kesalahan siswa dalam membaca soal.

Salah satu contoh kesalahan memahami soal yaitu terdapat soal cerita yang mengatakan bahwa "luas lahan si A $\frac{5 x}{6} h a$

lebih banyak dari lahan yang didapat si B" siswa hanya menuliskan $\frac{5 x}{6}$ ha tanpa

menjumlahkan dengan lahan si $\mathrm{B}$, jawaban seperti ini dapat dikatakan melakukan kesalahan memahami soal. Pada soal berikutnya, siswa salah dalam keterampilan proses, ada soal “ $\frac{3}{x+1}+\frac{4}{x}$, dan siswa menjawab:“

$\frac{3 . x}{x+1}+\frac{4(x+1)}{x}=\frac{3 x}{x^{2}+x}+\frac{4 x+1}{x^{2}+x}=\frac{7 x+1}{x^{2}+x}$, Jawaban

seperti ini dapat dikategorikan melakukan kesalahan keterampilan proses, karena siswa keliru dalam perhitungan $\frac{4(x+1)}{x}$, seharusnya 
siswa menuliskan hasil perhitungannya $\frac{4 x+4}{x^{2}+x}$.

Soal berikutnya yang menyatakan bahwa siswa salah dalam menentukan jawaban akhir yaitu pada soal “ $\frac{11 x}{6}+\frac{6 x}{13}$, siswa menjawab

“ $\frac{9 x}{5}+\frac{6 x}{7}=\frac{9 x .7}{35}+\frac{6 x .5}{35}=\frac{63 x}{35}+\frac{30 x}{35}=\frac{53 x}{35},$,

dari jawaban siswa dapat dikatakan bahwa siswa keliru menentukan jawaban akhir, seharusnya jawaban akhir yang benar yaitu “ $\frac{53 x}{35}$,"

Berdasarkan hal tersebut, dapat diketahui dampak bagi siswa kedepannya, salah satunya yaitu dapat dilihat pada nilai ulangan harian, dan cara siswa memahami materi matematika. Hal tersebut juga ditemui pada hasil ulangan harian siswa kelas VII A pada materi bentuk aljabar, diketahui terdapat 20 dari 26 orang siswa yang nilainya tidak mencapai nilai KKM yaitu 75. Hal tersebut terjadi karena siswa melakukan banyak kesalahan ketika mengerjakan soal ulangan harian, kesalahan-kesalahan tersebut disebabkan oleh pemahaman konsep siswa yang masih kurang, sehingga minimnya ketelitian siswa saat menghitung, siswa belum menghafal perkalian dan siswa belum memahami konsep menerjemahkan kalimat matematika dalam soal cerita.

Semua hal yang ditemukan di SMP Negeri 1 Waingapu bukanlah hal yang sepele, sehingga jika dibiarkan tanpa adanya penanganan maka akan berdampak buruk bagi siswa kedepannya. Hal ini dikarenakan, materi matematika selalu berkesinambungan pada setiap jenjang pendidikan, sehingga untuk melanjutkan materi berikutnya dibutuhkan pemahaman pada materi sebelumnya, selain itu dampak lain yang akan terjadi yaitu, dilihat pada hasil Ujian Nasional (UN) dimana hasil ujian tersebut merupakan syarat untuk lulus dari suatu lembaga pendidikan. Sehingga, penelitian ini diharapkan dapat menganalisis kesalahan siswa dan faktor-faktor yang mempengaruhi serta memberikan rekomendasi pada guru untuk meminimalisir kesalahan dalam penyelesaian soal tersebut.

\section{METODE PENELITIAN}

Pendekatan penelitian ini yaitu kualitatif. Pendekatan kualitatif ialah pengumpulan data alamiah yang digunakan untuk menjelaskan suatu kejadian dan lebih mengutamakan makna daripada generalisasi, penelitian ini menempatkan peneliti sebagai instrumen kunci (Anggito \& Setiawan, 2018). Jenis penelitian yaitu kualitatif deskriptif. Penelitian kualitatif deskriptif ialah pendeskripsian fakta, gejala, ataupun kejadian-kejadian secara terstruktur dan akurat tentang suatu populasi tertentu (Hardani et al., 2020). Penelitian dilakukan di SMP Negeri 1 Waingapu, Sumba Timur pada bulan September 2020 semester I tahun ajaran 2020/2021. Adapun subjek penelitian yaitu 5 orang siswa kelas VIIIA SMP Negeri 1 Waingapu, kepala sekolah dan guru matematika. Teknik pengumpulan data menggunakan tes, wawancara dan studi dokumen. Persentase kesalahan siswa diukur menggunakan rumus sebegai berikut:

$$
K_{i}=\frac{n}{N \times s} \times 100 \%
$$

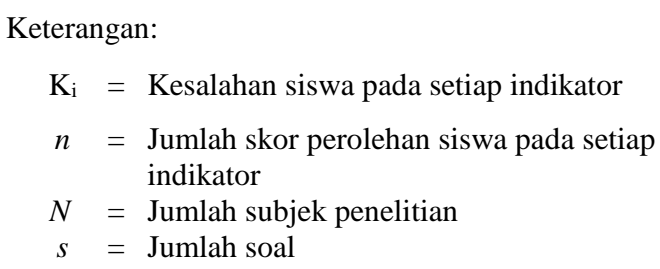

Teknik analisis data kualitatif menggunakan model Miles dan Huberman (1992) meliputi pengumpulan data, reduksi data, penyajian data dan penarikan kesimpulan (Sugiyono, 2013). Keabsahan data penelitian ini menggunakan teknik triangulasi, yang terdiri dari triangulasi sumber dan triangulasi teknik atau metode.

\section{HASIL DAN PEMBAHASAN}

\section{Hasil}

Berdasarkan hasil tes yang dilakukan terhadap 5 orang siswa menggunakan 6 butir soal selama 90 menit, siswa banyak melakukan kesalahan aturan matematika saat mengerjakan soal, hal itu juga didukung oleh pendapat Brown yang menyatakan bahwa kesalahan 
merupakan penyimpangan yang nyata serta kegagalan dalam memanfaatkan aturan yang telah ditetapkan sebelumnya (Yasim et al., 2018). Hasil analisis kesalahan siswa berdasarkan hasil tes seperti pada Tabel 1 .

Tabel 1. Analisis Kesalahan Siswa Berdasarkan Hasil Tes

\begin{tabular}{cccccc}
\hline \multirow{2}{*}{ SP } & \multicolumn{5}{c}{ Indikator Kesalahan Newman } \\
\cline { 2 - 6 } & $\mathbf{1}$ & $\mathbf{2}$ & $\mathbf{3}$ & $\mathbf{4}$ & $\mathbf{5}$ \\
\hline $\mathrm{AL}$ & 24 & 24 & 24 & 23 & 17 \\
$\mathrm{~N}$ & 24 & 24 & 6 & 6 & 6 \\
$\mathrm{~T}$ & 21 & 21 & 21 & 18 & 13 \\
$\mathrm{~S}$ & 24 & 24 & 24 & 22 & 10 \\
$\mathrm{~K}$ & 0 & 0 & 0 & 1 & 0 \\
\hline Total & $\mathbf{9 3}$ & $\mathbf{9 3}$ & $\mathbf{7 5}$ & $\mathbf{7 0}$ & $\mathbf{4 6}$ \\
\hline
\end{tabular}

Keterangan:

$$
\begin{aligned}
& \mathrm{SP}=\text { Subjek Penelitian } \\
& \mathrm{NS}=\text { Nomor Soal }
\end{aligned}
$$

Analisis hasil penelitian pada setiap jenis kesalahan siswa menurut Newman adalah sebagai berikut:

\section{a. Kesalahan Membaca (Reading Error)}

Kesalahan membaca yaitu kesalahan yang terjadi dikarenakan siswa salah membaca informasi yang terdapat pada soal, sehingga jawaban yang diberikan siswa tidak sesuai dengan maksud soal. Bukti hasil tes siswa dapat dilihat pada gambar 1 .

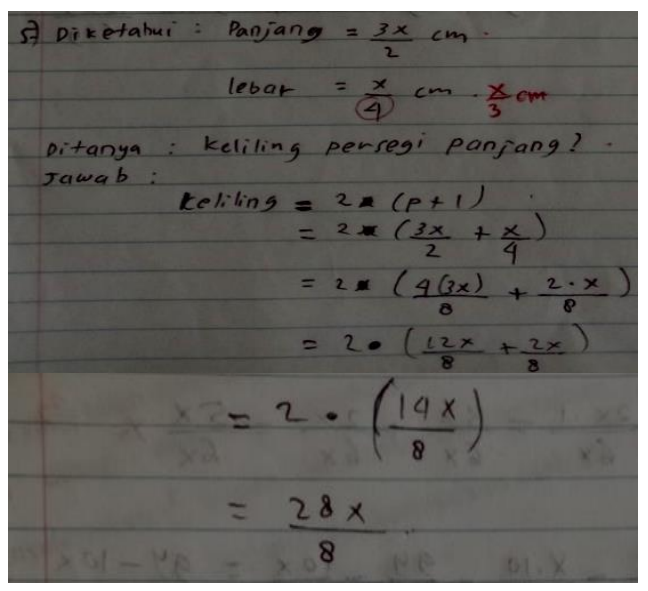

Gambar 1. Reading Error

Berdasarkan Gambar 1, hasil tes menunjukkan bahwa siswa melakukan kesalahan pada soal tes nomor 5 yaitu siswa salah menuliskan soal yang diketahui. Hal ini diperkuat dengan wawancara yang dilakukan kepada SP3 pada tanggal 7 Oktober 2020, yang mengatakan bahwa siswa kurang teliti dalam membaca soal, sehingga jawaban tidak sesuai dengan soal yang ditanyakan. Sehingga dapat disimpulkan kesalahan membaca siswa dalam mengerjakan soal dikategorikan sangat rendah yaitu sebesar $3,1 \%$.

\section{b. Kesalahan Memahami (Comprehension Error)}

Kesalahan memahami adalah kesalahan yang terjadi karena siswa tidak memahami informasi yang ditanyakan pada soal. Bukti hasil tes siswa dapat dilihat pada gambar 2 .

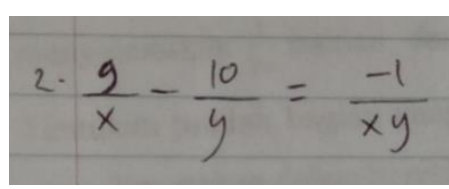

\section{Gambar 2. Comprehension Error}

Berdasarkan gambar 2. hasil tes menunjukkan siswa melakukan kesalahan pada soal tes nomor 2 yaitu siswa tidak memahami konsep pecahan, siswa langsung mengurangkan tanpa terlebih menyamakan penyebut. Sehingga dapat disimpulkan kesalahan memahami siswa dalam mengerjakan soal dikategorikan sangat rendah yaitu sebesar $3,1 \%$.

\section{c. Kesalahan \\ (Transformation Error) \\ Transformasi}

Kesalahan trenaformasi yaitu kesalahan yang terjadi akibat siswa belum mampu mengubah soal ke bentuk matematika secara benar, belum menentukan rumus yang akan digunakan dengan tepat. Bukti hassil tes siswa dapat dilihat pada gambar 3 .

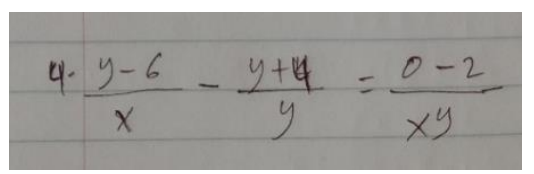

\section{Gambar 3. Transformation Error}

Berdasarkan gambar 3. hasil tes menunjukkan bahwa siswa melakukan kesalahan pada soal tes nomor 4 yaitu siswa tidak memahami konsep pecahan, siswa langsung menjawab soal dengan asal-asalan. Hasil tes menunjukkan bahwa siswa tidak dapat membuat model matematika dari informasi yang diperoleh, sehingga salah dalam penyelesaian akhir dari soal tersebut. 
Hal ini diperkuat dengan wawancara yang dilakukan kepada SP2 pada tanggal 6 Oktober 2020, yang mengatakan bahwa siswa tidak mengetahui rumus yang akan digunakan untuk menyelesaikan soal. Sehingga dapat disimpulkan kesalahan memahami siswa dalam mengerjakan soal dikategorikan sangat rendah yaitu sebesar 2,5\%

\section{d. Kesalahan Keterampilan Proses (Process Skill Error)}

Kesalahan keterampilan proses adalah kesalahan yang terjadi karena siswa belum terampil dalam menyelesaikan soal dan salah dalam melakukan perhitungan. Bukti hasil tes siswa dapat dilihat pada gambar 4 .

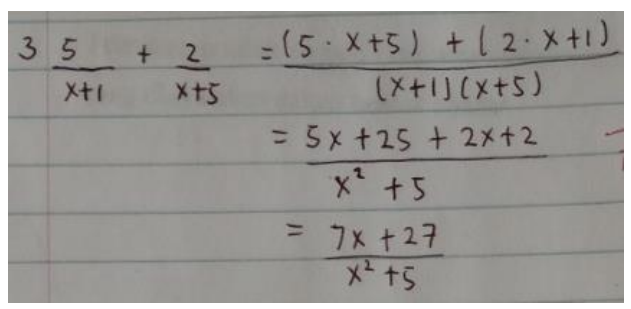

Gambar 4. Process Skill Error

Berdasarkan gambar 4. hasil tes menunjukkan bahwa siswa melakukan kesalahan pada soal 3 yaitu siswa salah melakukan penjumlahan aljabar pada pembilang. Hasil tes menunjukkan bahwa siswa melakukan kesalahan perhitungan serta salah menggunakan aturan matematika dengan benar, terutama dalam menyamakan penyebut pecahan aljabar. Hal tersebut diperkuat dengan wawancara yang dilakukan kepada SP4 pada tanggal 7 Oktober 2020, yang mengatakan bahwa siswa mengerjakan soal tes dengan terburu-buru, sehingga kurang teliti dalam menghitung, serta kurang memahami konsep pecahan. Sehingga dapat disimpulkan kesalahan memahami siswa dalam mengerjakan soal dikategorikan sangat rendah yaitu sebesar 2,33\%.

\section{e. Kesalahan Penentuan Jawaban Akhir (Encoding Error)}

Kesalahan penentuan jawaban akhir adalah kesalahan yang terjadi dalam menentukan jawaban akhir, serta tidak menuliskan kesimpulan. Hal ini juga banyak dilakukan oleh siswa ketika mengerjakan soal. Bukti hasil tes siswa dapat dilihat pada gambar 5.

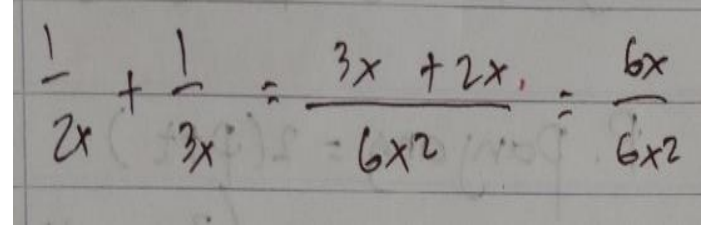

Gambar 5. Encoding Error

Berdasarkan hasil tes menunjukkan bahwa siswa melakukan kesalahan pada soal 3 yaitu siswa salah menentukan jawaban akhir karena kesalahan perhitungan. Hasil tes menunjukkan bahwa beberapa siswa tidak menuliskan hasil akhir dengan benar serta tidak membuat kesimpulan. Hal tersebut diperkuat dengan wawancara yang dilakukan terhadap SP1 pada tanggal 6 Oktober 2020, yang mengatakan bahwa siswa tidak menuliskan kesimpulan dikarenakan faktor lupa dan kebiasaan siswa yang tidak menuliskan kesimpulan pada soal cerita. Halhal tersebut juga diperkuat dengan hasil wawancara peneliti dengan guru matematika yang mengatakan bahwa siswa tidak menguasai materi dasar matematika, kurang fokus dalam proses pembelajaran di kelas, serta kurang peka dengan instruksi yang diberikan guru. Sehingga dapat disimpulkan kesalahan penentuan jawaban akhir siswa dalam mengerjakan soal dikategorikan sangat rendah yaitu sebesar $1,53 \%$.

\section{Pembahasan}

\section{Analisis Kesalahan Siswa}

Kesalahan membaca soal (reading error) dalam penelitian ini yaitu kesalahan siswa dalam melihat angka yang terdapat pada soal. Hal ini sesuai dengan penelitian Rahmawati dkk yang menyatakan bahwa siswa menulis kata-kata atau angka yang tidak terdapat dalam soal, sehingga jawaban siswa tidak sesuai dengan maksud soal (Rahmawati \& Permata, 2018).

Kesalahan memahami (Comprehension Error) dalam penelitian ini yaitu kesalahan yang terjadi karena siswa tidak menuliskan kembali soal yang diketahui, siswa langsung menjawab soal tanpa adanya langkah-langkah pengerjaan. Hal ini sejalan dengan hasil penelitian Rahmawati \& Permata (2018) yang mengatakan bahwa kesalahan ini terjadi karena siswa kurang memahami konsep, sehingga 
siswa tidak menuliskan apa yang diketahui dan ditanyakan pada soal

Kesalahan transformasi dalam penelitian ini yaitu kesalahan dalam penentuan rumus yang akan digunakan. Dari hasil pekerjaan siswa dilihat bahawa siswa memahami langkah-langkah pengerjaan, tetapi sulit menentukan rumus apa yang akan digunakan, siswa tidak memahami materi bentuk aljabar serta tidak menguasai konsep dasar pecahan.

Kesalahan keterampilan proses (process skill error) dalam penelitian ini, siswa salah dalam menggunakan aturan matematika dengan benar. Siswa melakukan kesalahan keterampilan proses jika siswa salah dalam melakukan prosedur atau salah melakukan perhitungan untuk mencari jawaban dari soal. Hal ini terjadi karena siswa mengerjakan soal tes dengan terburu-buru, sehingga kurang teliti dalam melakukan perhitungan (Rahmawati \& Permata, 2018).

Kesalahan penentuan akhir (encoding error) dalam penelitian ini yaitu, kesalahan menentukan jawaban akhir atau tidak menuliskan kesimpulan soal. Siswa dikatakan melakukan kesalahan pada hasil akhir jika siswa salah dalam menentukan, menulis atau menetapkan jawaban terakhir dari soal. Hal ini terjadi karena siswa terbiasa tidak menuliskan kesimpulan (Rahmawati \& Permata, 2018).

Pada kelima tipe kesalahan menurut Newman, berdasarkan hasil tes diketahui bahwa siswa melakukan 5 jenis kesalahan, dengan persentase kesalahan sebesar 3,1\% pada reading error dan comprehension error; $2,5 \%$ pada transformation error; $2,33 \%$ pada process skill error, dan 1,53\% pada encoding error. Berdasarkan persentase kesalahan siswa dalam menyelesaikan soal, jenis kesalahan yang paling banyak dilakukan oleh siswa yaitu pada encoding error dan comprehension error. Hasil penelitian ini cenderung sama dengan penelitian yang dilakukan oleh Safitri dkk yang menempatkan encoding error sebagai kesalahan yang paling banyak dilakukan oleh siswa (Safitri et al., 2019).

\section{Faktor Penyebab Kesalahan Siswa}

Melalui hasil analisis data yang dilakukan diketahui pula penyebab dari kesalahan yang dilakukan siswa. Beberapa penyebab siswa salah ketika mengoperasikan soal yaitu, siswa terburu-buru saat membaca soal dan tidak teliti dalam perhitungan, siswa tidak menguasai konsep operasi hitung pecahan, serta siswa tidak memahami materi bentuk aljabar. Didukung oleh penelitian yang dilakukan Heppinia \& Tiya (2015) menyatakan faktor penyebab siswa melakukan kesalahan ketika mengoperasikan soal pecahan yaitu, kurangnya kemampuan membaca soal, tidak teliti ketika menyelesaikan soal dan juga pemahaman konsep yang kurang terhadap materi operasi hitung bilangan pecahan. Faktor lain yang menyebabkan siswa melakukan kesalahan dalam mengerjakan soal pecahan yaitu kurangnya pemahaman konseptual tentang materi pecahan, dan juga kurangmya keterampilan siswa dalam mengerjakan operasi pada pecahan (Kusuma \& Retnawati, 2019).

Untuk mengatasi masalah di atas, rekomendasi tindakan yang harus dilakukan guru yaitu, dengan cara melakukan review materi dasar matematika seperti operasi hitung pecahan terkhusus pada operasi penjumlahan dan pengurangan pecahan serta materi operasi bentuk aljabar, juga siswa perlu diingatkan untuk memeriksa kembali pekerjaannya ketika selesai mengerjakan soal. Hal tersebut diperkuat oleh penelitian Ismail yang mengemukakan bahwa melakukan review materi dianggap dapat meningkatkan daya ingat siswa agar lebih mudah menerima pengetahuan baru, sehingga informasi yang disajikan dalam proses pembelajaran dapat disesuaikan dengan pengetahuan awal siswa.

\section{SIMPULAN DAN SARAN}

Berdasarkan hasil penelitian dan pembahasan disimpulkan bahwa siswa melakukan 5 jenis kesalahan, yaitu: 3,1\% pada reading error dan comprehension error; 2,5\% pada transformation error; $2,33 \%$ pada process skill error, dan 1,53\% pada encoding error. Berdasarkan hasil persentase kesalahan siswa dalam penyelesaian soal, kesalahan yang banyak ditemukan ialah pada encoding error dan comprehension error. Adapun kesalahan siswa disebabkan oleh faktor penyebab yaitu, siswa terburu-buru saat membaca soal dan tidak teliti ketika 
menghitung, siswa tidak menguasai konsep operasi hitung pecahan, serta siswa tidak memahami materi bentuk aljabar. Mereview materi dasar matematika oleh guru merupakan tindak lanjut yang dapat dilakukan guna mengatasi kesalahan-kesalahan tersebut.

Berdasarkan hasil penelitian, beberapa saran diberikan bagi beberapa pihak. Bagi guru hendaknya mengingatkan materi prasyarat yang dibutuhkan pada awal pembelajaran. Bagi siswa perlu membiasakan diri memeriksa kembali jawaban serta tidak perlu terburu-buru dalam mengerjakna soal. Bagi peneliti selanjutnya yaitu melengkapi penelitian ini dengan mengungkapkan lebih banyak faktor penyebab siswa melakukan kesalahan dalam menyelesaikan soal matematika.

\section{DAFTAR PUSTAKA}

Ananda, R. P., Sanapiah, S., \& Yulianti, S. (2018). Analisis Kesalahan Siswa Kelas Vii Smpn 7 Mataram Dalam Menyelesaikan Soal Garis Dan Sudut Tahun Pelajaran 2018/2019. Media Pendidikan Matematika, 6(2), 79. https://doi.org/10.33394/mpm.v6i2.18 38

Anggito, A., \& Setiawan, J. (2018). Metodologi penelitian kualitatif. CV Jejak (Jejak Publisher). Google Scholar

Hardani, H. A., Ustiawaty, J., Istiqomah, R. R., Fardani, R. A., Sykmana, D. J., \& Auliya, N. H. (2020). Buku metode penelitian kualitatif \& kuantitatif. Yogyakarta: CV. Pustaka Ilmu Group. Google Scholar

Heppinia, M., \& Tiya, K. (2015). Analisis Kesalahan Siswa Kelas VII SMP Negeri 1 Wawotobi Dalam Menyelesaikan Soal-Soal Pecahan. Jurnal Penelitian Pendidikan Matematika, 3(3), 27-40. http://ojs.uho.ac.id/index.php/JPPM/art icle/view/3018

Kemendikbud. (2019). Hasil Ujian Nasional Tahun 2019. Kemendikbud. Tersedia di

https://hasilun.puspendik.kemdikbud.g o.id/\#2019!smp!capaian!24\&12\&999! $\mathrm{T} \& \mathrm{~T} \& \mathrm{~T} \& \mathrm{~T} \& 1 \& ! 3 ! \&$

Kusuma, U. I., \& Retnawati, H. (2019). Analysis of Sixth Graders' Difficulties in Solving Mathematics Word Problems on Whole Numbers, Fractions, and Decimals. Journal of Physics: Conference Series, 1320(1), 012008. https://doi.org/10.1088/17426596/1320/1/012008

Oktaviani, U., Kumawati, S., Apriliyani, M. N., Nugroho, H., \& Susanti, E. (2020). Identifikasi Faktor Penyebab Rendahnya Hasil Belajar Matematika Peserta Didik di SMK Negeri 1 Tonjong. MATH LOCUS: Jurnal Riset Dan Inovasi Pendidikan Matematika, 1(1).

https://doi.org/10.31002/mathlocus.v1i 1.892

Depdiknas. (2006). Permendiknas Nomor 22 Tahun 2006 Tentang Standar Isi. Depdiknas. Jakarta. Google Scholar

Rahmawati, D., \& Permata, L. D. (2018). Analisis kesalahan siswa dalam menyelesaikan soal cerita program linear dengan prosedur newman. Jurnal Pembelajaran Matematika, 5(2), 173-185. https://jurnal.uns.ac.id/jpm/article/vie $\mathrm{w} / 26050$

Rohmah, M., \& Sutiarso, S. (2018). Analysis problem solving in mathematical using theory Newman. EURASIA Journal of Mathematics, Science and Technology Education, 14(2), 671-681. https://doi.org/10.12973/ejmste/80630

Safitri, F. A., Sugiarti, T., \& Hutama, F. S. (2019). Analisis kesalahan siswa dalam menyelesaikan soal cerita bangun datar berdasarkan Newman's Error Analysis (NEA). Jurnal Profesi Keguruan, 5(1), 42-49. https://journal.unnes.ac.id/nju/index.ph p/jpk/article/view/18465

Siagian, M. D. (2016). Kemampuan koneksi matematik dalam pembelajaran matematika. MES: Journal of 
Jesisca L. T. Mangi, Elsy Senides H. Taunu, Mega R. Wulandari, Anggriati Ledu Ngaba, Yuliana Tamu Ina Nuhamara, Mayun Erawati Nggaba

Analisis Kesalahan Siswa dalam Menyelesaikan Soal Operasi Pecahan Bentuk Aljabar SMP

Prima Magistra: Jurnal Ilmiah Kependidikan Volume 3, Nomor 1, Januari 2022, hal 85-91

Mathematics Education and Wandini, R. R. (2019). Pembelajaran

Science, 2(1), 58-67. Matematika Untuk Calon Guru Mi/Sd

https://jurnal.uisu.ac.id/index.php/mes (O. K. Banurea (Ed.); 1st ed.). CV. uisu/article/view/117

Widya Puspita. Google Scholar

Sugiyono, S. (2013). Metode Penelitian Yasim, S., Hasnawiah, H., \& Roni, R. (2018). Pendidikan Pendekatan Kuantitatif, $\quad$ Error Analysis in Using Passive Voice. Kualitatif dan R\&D. Bandung: EDUVELOP, 2(1), 48-56. Alfabeta. Google Scholar https://doi.org/10.31605/eduvelop.v2i1 .23 